\title{
A Website Quality Model Investigating the Loyalty of South African Consumers towards Travel
} Websites

\author{
0. Omoruyi \\ Vaal University of Technology, South Africa \\ osayuiwameno@vut.ac.za
}

\begin{abstract}
Due to the increase in the need for travel by international visitors, it is important that organisations consider key attributes of website quality, namely information quality and system quality to encourage and enhance consumer loyalty overtime. Drawing from Delone and McLean's theory, this research argues that information quality and system quality are antecedents of travel website quality, of which the latter is a predictor of consumer loyalty. A quantitative research approach was adopted by way of a survey methodology and data were analysed usingSmart PLS software for structural equation modelling (SEM). Based on the theoretical review, a research framework detailing the hypotheses relationships among the research constructs was developed. Based on the research findings, the results provide support for the proposed positive relationships among the research constructs.
\end{abstract}

Keywords: Information quality, system quality, travel websites quality, loyalty

\section{Introduction}

The concept of quality is well known and widely researched globally due to the importance of quality assessment-related issues present in almost every organisation (Cai \& Jun, 2003; Elassy, 2015; Wu \& Chang, 2016). Therefore, website quality should be the top priority of travel websites. This is because the absence of quality as a fundamental principle of sound business management to address customer-specific needs and expectations could result in brand destruction, poor customer confidence, a decrease in performance and the gradual and continuous erosion of profits, performance and competitive position. According to Monczka, Handfield, Giunipero and Patterson (2016:287), quality can be defined as "the total composite of product and service characteristics of marketing, engineering, manufacturing and maintenance through which the product or service in use will meet or exceed the expectations of the customer". The International Standards Organisation (ISO, 9000) defines quality as the totality of features and characteristics of a product or service that seeks to enhance customer satisfaction and continual improvement based on quality standards (ISO, 2009). Therefore, ensuring the overall website quality is key to website competitive success and business development. The conceptualisation of quality differs and may be somewhat subjective or understood differently depending on the context in which it is used. For example, in businesses, manufacturing and in the engineering sectors, quality is construed only as non-inferiority, superiority and fitness for use of something whereas in public service sectors, quality is viewed as nothing more than simple conformance to standards (Elassy, 2015). On the other hand, service marketers regard quality within the customer's perceptual lens after a service encounter, thereby viewing the phenomenon as the "evaluation of employee interaction, the service environment and the service outcome" (Chumpitaz \& Paparoidamis, 2004). Interestingly, within the healthcare sector, quality is related to structure, processes and outcomes that are consistent with current professional knowledge that surpassed the desire outcome (Hillner, Smith \& Desch, 2000).

DeLone and McLean consider quality to be an essential component in determining success within an information system (Roy \& Balaji, 2015). In their view, quality should be improved, strategically because of its significant impact on consumers' views and responses to online products or services. Because of their proposition, contemporary scholars now believe that the increase in competition among marketing organisations has proffered the need for significant capital investments in both system and online information quality (Roger-Monzo, Marti-Sanchez \& Guijarro-Garcia, 2015; Zhao, 2016; Silva \& Goncalves, 2016). Specifically, among online businesses, quality is related to both data quality (content richness) and website quality (ease of use) (Law \& Bai, 2008). The latter definition is the focus of this study. Due to increase competition among travel industries, the use of information technology, especially in terms of 'internet of things' as the biggest agent of change, is changing the way travel organisations operate and changing customer's interaction and perception towards travel website. With this, it is therefore important to address the antecedent of customer loyalty towards travel organisations website. To efficiently and effectively satisfy 
the needs of the new digital consumers, the research model proposed that the level information quality as well as system quality significantly influence travel website quality and thereby enhancing customer loyalty towards the website.

\section{Theoretical Background and Hypotheses Development}

DeLone and Mclean's information system success theory has been used by many researchers to measure dependent variables (Zhang, Min, Liu \& Liu, 2013; Lwoga, 2013; Hazen, Huscroft, Hall, Weigel \& Hanna, 2014; Xinli, 2015). In the theory, six latent variables, namely information quality, system quality, use, user satisfaction, individual impact and organisational impact were used to provide a compressive definition of information systems success (Delone \& McLean, 2002; Bokhari, 2005; Petter \& McLean, 2009; Moghavvemi \& Salleh, 2014; Tam \& Oliveira, 2016). Therefore, the model is important to understanding the value and efficacy of investing in online information quality as well as system quality management along websites. The theory evaluates the importance of information quality and system quality as determinants of online user satisfaction and websites organisational success impact (Xinli, 2015; Roy \& Balaji, 2015). While the theory is beset with integrated undertones, the focus of this paper is domain-specific; hence, the need to focus only on the quality attributes that are relevant within the realms of travel websites. Notably, quality is a predictor of the effectiveness of a website from the perspective of the consumer (Lin, 2007). Thus, website quality is expected to be a determinant of online retailer success as well.

Travel website quality: According to Stats SA 2015, travel organisations in South Africa have contributed significantly to economic development. For example, 32186 new jobs were created in 2015 and contributed about 3.1 percent to the GDP, which makes the travel industry an important sector in the South Africa economy. The reliance on travel websites by consumers for effective information, travel planning, decisionmaking and destination priority forecasting has increased and will continue increasing as travel organisations continue to offer greater products/service selection and quality efficiency (Bai, Law \& Wen, 2008; Cao \& Yang, 2016). South Africa, is a rainbow economy with renowned tourist attractions; hence, fuelling the evident trajectory in the demand for efficient travel websites. One key enabler, the Internet as "the digital revolution's biggest enabler and meta information source", drives the efficacy of travel websites (Wang, Law, Hung \& Fong, 2015). In particular, internet technology has become an amazing tool for marketing organisations to promote their products while simultaneously communicating helpful information resources such as restaurants, transportation, attractions and hotels to consumers (Amaro \& Duarte, 2015; IsfandyariMoghaddam, 2016; Cao \& Yang, 2016; Bronner \& De Hoog, 2016). The Internet bridges the gap between marketing organisations and consumers seeking to make reservations pertaining to airlines, cruise lines, lodging as well as car rentals (Amaro\& Duarte, 2015). Consumers use websites as a sources of up-to-date travel information for first-hand visual experience of the destination image (pictures, maps, reference rate and facilities) across local and international travel destinations (Ghasemaghaei \& Hassanein 2015; Sowteret al., 2016; Tseng \& Wang, 2016). In doing so, both existing and potential customers tend to assess the efficacy of companies within the travel industry based on service quality specifications corresponding with customer expectations (Chen et al., 2017).

Aladwani and Palvia (2002:469) define website quality as "users' evaluation of a website's features, regarding the extent to which the site meets users' needs and expectations, thereby reflecting overall excellence of the website". While there exist too many bones of contention within the literature regarding the constituents of website quality, Dedeke (2016) states that determining travel websites quality should incorporate an assessment of the "travel website's product information and its non-product-related website attributes such as ease of use, entertainment, visual appeal, responsiveness, speed and web security". This study considers the predictive power of website quality on behavioural loyalty of consumers towards travel websites in South Africa. Consistent with Roky and Al Meriouh (2015), both information quality and system quality are regarded as value components of overall travel website quality, should consumers or suppliers be expected to initiate transactions and return to websites on a regular basis.

Information quality: The amount of information available globally is increasingly growing particularly on the Internet (King, Walpole \& Lamon, 2007; Cheema \& Papatla, 2010; Chen, Huang \& Davison, 2017). However, for information to be effective to its readers, it should be of quality (Sowter, Astin, Dye, Marshall \& 
Knapp, 2016). Of note, leisure travellers, business travellers, tourists and travel professionals rely on website information to optimise and maximise their travel planning decisions (Xiang, Magnini \& Fesenmaier, 2015). As such, the emergence of the information age along with new technology and related applications, information explosion from different sources as well as the growth in the method of information dissemination has called for the need for improvement in information quality (Ghasemaghaei \& Hassanein 2015). According to Chavez et al. (2015), information quality refers to information richness rather than the amount thereof, thereby determining the success of travel websites. This could include content-related aspects such as accuracy, timeliness, completeness, relevance, understandability, consistency and security of online information (DeLone \& McLean, 2003). Webster and Williams (2005) included that the readability, accessibility of information on the website as well as the effective use of technology, accurate timely feedback, website design and website content determine website quality.

As already pointed out, the significance of information quality is based on essential characteristic features including the accuracy, sufficiency and completeness of information (Kuan, Bock \& Vathanophas, 2008; Ponte, Carvajal-Trujillo \& Escobar-Rodriguez, 2015). In the same vein, other scholars have added the elements of ease of use and relevance of the information (Bai, Law \& Wen, 2008; Chavez, Yu, Gimenez, Fynes \& Wiengarten, 2015; Marinagi, Trivellas \& Reklitis, 2015). Nevertheless, the quality of information depends on how the information is perceived, trusted and used by consumers (Ghasemaghaei \& Hassanein, 2015). Chua and Banerjee (2016) adopt a triple-perspective approach upon conceptualising information quality whereby they incorporate comprehensibility, specificity and reliability of the information. The scholars assert that comprehensibility refers to the extent to which the information is easy to understand, while specificity relates to the extent to which the information is relevant to aid travel website quality and purchase decisions. On the other hand, reliability refers to the extent to which the information is dependable for consumers. In this work, information quality isoperationalised as consumer's perceptions about the completeness and accuracy of information presented on a travel website'. Therefore, information quality of a travel website is deemed to impact positively on the usefulness of travel websites, thereby evoking overall website quality evaluations by consumers. This study then proposed that:

H1: information quality has a significant positive influence on travel websites quality.

System quality: Owing to the growing competition among travel organisations, enhancing and providing enhanced system quality that increase consumers' satisfaction and builds long-term consumer loyalty is important. Websites system quality is defined as the "navigational scheme and hierarchy used on a website together with its design, comprising elements such as visual appeal, innovativeness, aesthetics and use of colours and shapes" (Dedeke, 2016:542). According to Zheng, Zhao and Stylianou (2009), website system quality depends largely on the website's design attributes, such as navigation, content organisation and security. Relatedly, within the D\&M, system, quality is measured by elements of technical success such as ease-of-use, functionality, reliability, flexibility, data quality, portability, integration and importance (Delone \& McLean2002). Of note, system quality has been identified as a valid dimension of overall website quality, with the latter contributing significantly to repeat visits and loyalty towards websites (Hsuet al., 2014). Dedeke (2016) posits that online shoppers do not shop on poorly designed websites. Nevertheless, consumers can only commit to a travel website owing to the quality design attributes of that particular travel website. Relatedly, the literature revealed that the content of a website coupled with its design elements could impact positively on overall quality evaluations, thereby leading to enhanced trust and loyalty towards the website (Petter \& McLean, 2009). Therefore, this study proposed that:

$\boldsymbol{H}_{2}$ : system quality has a significant positive influence on travel websites quality.

Website quality and behavioural loyalty of consumers: A high quality website gains trust from consumers and thereby boosts overall product sales. In other words, whatever influences the intention to make travel reservations on travel websites largely depends on the consumer quality perceptions about the travel website (Law \& Bai, 2008). According to Wolfinbarger and Gilly (2003), website quality is related to customer satisfaction, retention and loyalty in both product and service settings. Consequently, it seems reasonable to suggest that the quality the consumer perceives along travel websites could have a direct influence on overall loyalty towards the site. Loyalty is determined greatly by the re-patronage intentions of consumers towards a particular website, which may be due to positive quality perceptions and/or satisfaction with the system quality in general. Therefore, this implies that website quality plays a significant role in determining online 
consumer loyalty. Wang et al. (2015) define consumer loyalty as the consumer's willingness to continuously purchase and participate in an online deal (travel websites). Relatedly, Cry, Hassanein, Head and Ivanov (2007:45) define online loyalty as "consumers' intention to re-visit a website or to purchase from it in the future". Toufaily, Ricard and Perrien (2013:1437) conceptualised online consumer loyalty as "the consumer's willingness to maintain a stable relationship and to engage in repeat visitation or purchases online, while using the company's website as the first choice among alternatives". The definitions proffered by these scholars attest to the behavioural component of customer loyalty, which is the variable of interest in this research. This is because while attitudinal loyalty may trigger purchases, it is usually of a latent nature and could be viewed as inadequate with regard to explaining the behaviour of consumers who make reservations and purchases on travel websites. This study, therefore, purports that website quality is a strategic force that could lead to consumer loyalty towards travel websites. Thus:

$\boldsymbol{H}_{3}$ : Website quality has a significant positive influence on consumer loyalty.

Following on from the extant literature as well as the hypotheses developed in this research, a conceptual model was developed and tested (Figure 1). In the model, both information quality and system quality are considered the predictor variables that explain the overall website quality perceptions of South African travel consumers, whereas the latter evokes behavioural loyalty.

\section{Methodology}

This study adopted a quantitative approach to evaluate a research model of travel website quality. The approach was deemed appropriate as it enabled the researchers to objectively test and confirm the hypotheses and to explain the influence of the selected website quality attributes on overall customer loyalty towards travel websites.

Instrument and data collection: The data collection process involved consumers currently residing within the Southern Gauteng, South Africa. Due to the nature of the research, the targeted research participants comprised consumers who had previous experience with making travel reservations from selected South African travel websites. A structured questionnaire comprising four research constructs was used in line with the work of previous scholars. In particular, the scales used by Kuan, Bock and Vathanophas (2008) as well as Zhang and Seydel (2005) were adapted to measure both information quality and system quality, respectively. In addition, the overall website quality scale developed by Yoo and Donthu (2001) as well as the behavioural loyalty scale used by Bernardo, Marimon and Alonso-Almeida (2012) were used with necessary modifications made to fit the present research context and purpose. The scale items were anchored along a five-point Likert-type scale covering the questions relating to the four annotated constructs (IQ, SQ, WQ and LO). The scale items used in this work are included as Appendix 1. Moreover, the questionnaire comprised demographic questions, which incorporated information relating to the website habits of travel consumers. This data was needed to establish a detailed profile for the sample. To eliminate differences in response patterns due to different reference points, the respondents were requested to answer the questionnaire with reference to their favourite travel website, where they have previously made a reservation, within the past 12 months. Where the respondents were not sure, the research assistants guided them as they answered the questionnaire. The sample side decision was based on previous studies. Researchers such asLaw and Bai (2008), Tung (2012), Hsu, Chang, Chu and Lee (2014), Tsao, Hsieh \& Lin (2016), Jeon \&Jeong (2017), examines the influence of information quality and system quality on travel website quality using sample size ranging from 250 to 800 . Based on this evidence, the sample size for this study was set at $300.0 \mathrm{f}$ the 300 questionnaires distributed, 189 were considered usable for eventual data analysis after conducting a datasort cleaning procedure, thereby representing a response rate of 63 percent.

\section{Results}

To analyse statistically the measurement and structural models, this study used SEM technique (Ringle, Wende \& Will, 2005). This study commences the data analysis section by coding the data in Excel spreadsheet and cleaning the data for missing entries and double entries. This was followed by descriptive statistics and confirmatory factor analysis. Finally, the path modelling, which tested the hypothesised relationships, was performed and research findings were discussed. 
Profile of the respondents: The respondents were asked to report their demographic information, including gender, age, marital status and education. Out of a sample set of 189 responses that were considered usable for the eventual run of data analysis, most of the respondents were female (59.5\% of the sample). In addition, the median age group of the respondents was between 31 to 40 years (55.4\% of the sample). Nevertheless, approximately 58 percent of the respondents were single while 79.4 percent of the respondents had either high school ( $53 \%$ of the sample) or university degree as the highest level of education $(26.4 \%$ of the sample).

Preliminary descriptive results: Table 1 presents the descriptive statistics extracted from the study. The higher mean values (above 3.0) indicated below are associated as reflecting greater agreement by participants considering that a five-point Likert scale was utilised. The items included in this study reported acceptable mean values along information quality $(3.029 \leq \overline{\mathrm{x}} \leq 3.854)$, system quality $(3.315 \leq \overline{\mathrm{x}} \leq 3.894)$, website quality $(3.298 \leq \overline{\mathrm{x}} \leq 3.645)$ and loyalty $(3.037 \leq \overline{\mathrm{x}} \leq 3.648)$. In addition, standard deviation values close to 1.00 were reported in this research, inferring the proximity of the scale items around the arithmetic mean.

SMART-PLS measurement model results: To analyse statistically the measurement and structural models, this study used Smart PLS software for SEM technique (Ringle, Wende \& Will, 2005). In SEM, the measurement model refers to the linkages between the latent variables and their manifest variables and the structural model captures the hypothesised causal relationships among the research constructs (Wetzels, Odekerken-Schroder \& Van Oppen, 2009). Unlike AMOS and LISREL, which are covariance-based approaches, Smart PLS is a regression-based technique that originates from path analysis. Smart PLS has emerged as a powerful approach to study causal models involving multiple constructs with multiple indicators. Smart PLS - a component-based method - has an ability to model latent constructs that are uncontaminated by measurement error under conditions of non-normality. It can handle complex predictive models in small-tomedium sample sizes. Since the current study sample size is relatively small (189), Smart PLS was found more appropriate and befitting for this work. In this respect, bootstrapping resampling method was used to test the statistical significance of the relationships. This procedure entailed generating 200 sub-samples of cases randomly selected, with replacement from the original data.

Table 1: SMART-PLS results

\begin{tabular}{|c|c|c|c|c|c|c|c|c|c|c|}
\hline \multirow{2}{*}{$\begin{array}{l}\text { Research } \\
\text { constructs }\end{array}$} & \multirow[b]{2}{*}{ Indicators } & Descriptive & \multicolumn{3}{|c|}{ Reliability statistics } & \multicolumn{4}{|c|}{ Validity statistics } & \multirow{2}{*}{$\begin{array}{l}\text { Collinearity } \\
\text { VIF }\end{array}$} \\
\hline & & $\begin{array}{l}\text { Mean SD } \\
(\bar{x})\end{array}$ & $\begin{array}{l}\text { Alpha } \\
(\alpha)\end{array}$ & Rho & CR & AVE & $\sqrt{A V E}$ & $\begin{array}{l}\text { Factor } \\
\text { loading }\end{array}$ & $\begin{array}{l}\text { Item-total } \\
\text { correlation }\end{array}$ & \\
\hline & IQ1 & 3.8541 .505 & & & & & & 0.774 & 0.655 & \\
\hline $\begin{array}{l}\text { Information } \\
\text { quality }\end{array}$ & IQ2 & 3.2871 .390 & 0.749 & 0.748 & 0.856 & 0.665 & 0.815 & 0.843 & 0.565 & 1.015 \\
\hline & IQ3 & 3.0291 .507 & & & & & & 0.828 & 0.760 & \\
\hline $\begin{array}{l}\text { System } \\
\text { quality }\end{array}$ & $\begin{array}{l}\text { SQ1 } \\
\text { SQ2 } \\
\text { SQ3 }\end{array}$ & $\begin{array}{ll}3.315 & 1.478 \\
3.894 & 1.402 \\
3.416 & 1.299\end{array}$ & 0.818 & 0.827 & 0.879 & 0.644 & 0.803 & $\begin{array}{l}0.806 \\
0.810 \\
0.817\end{array}$ & $\begin{array}{l}0.782 \\
0.570 \\
0.497\end{array}$ & 1.015 \\
\hline $\begin{array}{l}\text { Travel } \\
\text { website } \\
\text { quality }\end{array}$ & $\begin{array}{l}\text { WQ1 } \\
\text { WQ2 } \\
\text { WQ3 } \\
\text { WQ4 }\end{array}$ & $\begin{array}{ll}3.347 & 1.431 \\
3.363 & 1.272 \\
3.298 & 1.293 \\
3.645 & 1.443\end{array}$ & 0.770 & 0.791 & 0.866 & 0.682 & 0.826 & $\begin{array}{l}0.777 \\
0.838 \\
0.781 \\
0.857\end{array}$ & $\begin{array}{l}0.482 \\
0.469 \\
0.534 \\
0.366\end{array}$ & 1.000 \\
\hline Loyalty & $\begin{array}{l}\text { L01 } \\
\text { LO2 } \\
\text { L03 } \\
\text { L04 }\end{array}$ & $\begin{array}{ll}3.433 & 1.373 \\
3.648 & 1.394 \\
3.037 & 1.218 \\
3.079 & 1.227\end{array}$ & 0.711 & 0.719 & 0.812 & 0.521 & 0.722 & $\begin{array}{l}0.778 \\
0.733 \\
0.749 \\
0.616\end{array}$ & $\begin{array}{l}0.605 \\
0.523 \\
0.496 \\
0.578\end{array}$ & 1.049 \\
\hline
\end{tabular}

Note: Alpha $(\alpha)=$ Cronbach's alpha; Rho= Dillon-Goldstein's rho; CR=Composite reliability; AVE=Average variance extracted 
Reliability of this research was assessed by evaluating three statistical measures. According to Table 1, Cronbach's alpha coefficient values (ranging between 0.711 and 0.818), Dillon-Goldstein's rho estimates (ranging between 0.719 and 0.827 ) as well as CR values (ranging between 0.812 and 0.879 ) all exceeded the expected threshold of 0.70 inferring internally consistent scale reliability in this work. The reported results indicate that this research was reliable (Hair et al., 2011). To ensure convergent validity, the researcher checked if items loaded on their respective (a priori) constructs with loadings greater than 0.70 (save for indicator L04=0.616) were reported across the scale used in this research, which Malhotra (2010) considers ideal. Nevertheless, the individual items satisfied the 0.50 minimum threshold recommended by Anderson and Gerbing (1988) while an observation of the inter-total correlation value (LO4=0.578) for the indicator, which was greater than 0.30 (Field, 2009) suggested that the indicator could be retained. In addition, L04 was retained in this study based on review feedback from an expert debriefing session, which noted that the elimination of this indicator would have theoretical implications for the overall explanation of the loyalty construct. While this is so, the AVE values were computed to evaluate if the scale indicators resonated in theoretically accurate ways with their respective constructs. All AVE values were above 0.50, which is regarded as acceptable by Fraering and Minor (2006) since more than 50 percent of each item's variance was shared with its respective construct. Together, these results provided evidence for acceptable convergent validity in this research. Fornell and Larcker's (1981) criterion was employed upon assessing discriminant validity of this study as shown on Table 2 .

Table 2: Correlation analysis results and discriminant validity measures

\begin{tabular}{|c|c|c|c|c|}
\hline Construct & Information quality & System quality & Website quality & Loyalty \\
\hline Information quality & 1 & & & \\
\hline System quality & $0.123^{* *}$ & 1 & & \\
\hline Website quality & $0.417^{* *}$ & $0.664^{* *}$ & 1 & \\
\hline Loyalty & $0.610^{* *}$ & $0.189^{* *}$ & $0.527^{* *}$ & 1 \\
\hline $\begin{array}{l}\text { Square root } \\
\text { of } A V E\end{array}$ & 0.815 & 0.826 & 0.722 & 0.803 \\
\hline
\end{tabular}

${ }^{* *}$ Correlation is significant at the 0.01 level (2-tailed)

The square root of AVE values should be greater than the highest correlation coefficient for the constructs to bear theoretical and practical uniqueness (Fornell \& Larcker, 1981). Furthermore, if the estimated HTMT values are below 0.90 , discriminant validity has been established between the reflective constructs of a study (Henseler et al., 2015). In this study, the square roots of the AVE values range between 0.722 and 0.826 , which is greater than the highest inter-construct correlation value $(r=0.664)$. Relatedly, the computed HTMT ratios were in the range between 0.123 and 0.610 , which is sufficient evidence of the uniqueness of each construct in the research model.

Multicollinearity assessment: In terms of multicollinearity assessment, Hair et al. (2011) posit that VIF values greater than 5.0 indicate that the levels of collinearity within a data set are very high, therefore, problematic. An alternative method to evaluate collinearity concerns is by computing a bivariate matrix with correlation coefficients greater than $0.60(r>0.60)$ signalling collinearity issues in PLS path models. According to Table 2, all reported correlation values were less than 0.80 (highest $r=0.664$ ) while the VIF values ranged between 1.000 and 1.049, evidencing absence of multicollinearity in this research while t-statistics derived from bootstrapping (200 resamples) were greater than 1.96, implying statistical significant loadings at $p=0.001$. As such, this confirms that all the measurement items converged well on their respective constructs, therefore, are acceptable measures.

Path model results: PLS 3.0 also generates the path coefficients for the relationships modelled among the constructs. The significance of these coefficients was assessed using the bootstrap procedure that provided 
the t-values for each path estimate. Figure 1 and Table 3 present the results of the PLS analysis on the structural model along with the path estimates and t-values. Support for the study hypotheses, which are labelled on their corresponding paths in Figure 1, could be ascertained by examining the directionality (positive or negative) of the path coefficients and the significance of the $t$-values (greater than 1.96). Moreover, the standardised path coefficients are expected to be at least 0.20 and preferably greater than 0.3 (Chin, 1998).

Figure 1: PLS 3.0 model results

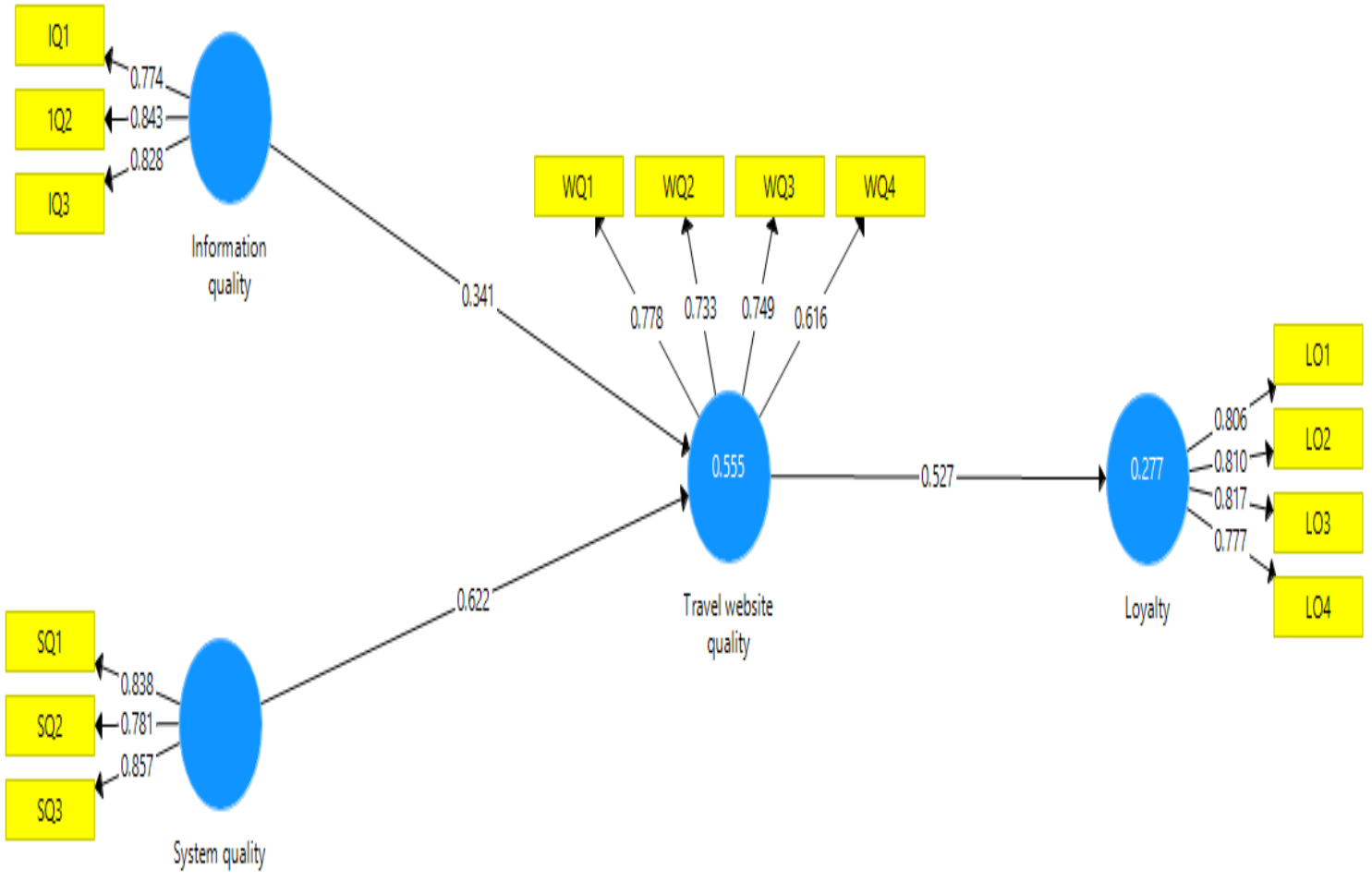

The results provide support for the proposed positive relationships between the three relationships $\left(\mathrm{H}_{1}, \mathrm{H}_{2}\right.$ and $\mathrm{H}_{3}$ ). Figure 1 and Table 3 provide the inner model results and subsequent decision to conclude the supported hypotheses.

Table 3: Final Model Fit

\begin{tabular}{lllll}
\hline $\begin{array}{l}\text { Proposed path } \\
\text { relationship }\end{array}$ & Hypothesis & Path coefficient & T-value & Outcome \\
\hline $\mathrm{WQ} \longleftarrow \mathrm{Q}$ & $\mathrm{H}_{1}$ & 0.341 & 4.836 & Supported \\
$\mathrm{WQ} \longleftarrow \mathrm{Q}$ & $\mathrm{H}_{2}$ & 0.622 & 9.561 & Supported \\
$\mathrm{LO} \longleftarrow \mathrm{WQ}$ & $\mathrm{H}_{3}$ & 0.527 & 7.978 & Supported \\
\hline
\end{tabular}

Following formulae provided by Tenenhaus, Vinzi, Chatelin \& Lauro, (2005), the global goodness-of-fit (GoF) statistic for the research model was calculated. Generally, GoF may still be useful in assessing which PLS-SEM 
datasets explain better. While GoF values vary from zero to one, higher values reflect better explanations (Henseler et al., 2015). The calculated global GoF is 0.64, while NFI is reported 0.903. Thus, this study concludes that the research model has a good overall fit.

Discussion: The main goal of this study was to propose and empirically test an integrated model of the antecedents of South African consumers' loyalty towards travel websites, while proving the importance of website quality as a second-order construct in the model. Figure 1 and Table 3 indicate that both information quality (path estimate $=0.341 ; \mathrm{p}=0.00<0.05$ ) and systems quality (path estimate $=0.622 ; \mathrm{p}=0.00<0.05$ ) have a significant positive influence on travel website quality. Together, the two dimensions, namely information quality and systems quality $\left(\mathrm{R}^{2}=0.555\right)$ explain about 56 percent of consumers' overall perceptions regarding the quality of South Africa travel websites as convergence points for making holiday reservations. Moreover, website quality has a direct effect on loyalty (path estimate $=0.527 ; p=0.00<0.05$ ) with only 28 percent explanatory power $\left(\mathrm{R}^{2}=0.277\right)$. Consistent with the first hypothesis formulated in this work, the significant path shows that information quality is a predictor of the overall quality of travel websites; hence, $\mathrm{H}_{1}$ is supported. Relatedly, Tung (2012); Ghasemaghaei and Hassanein (2015); Sampaio, Dong \& Sampaio (2015), provide additional support that information quality is a predictor of overall website quality in the sense that, as competition grow wide, travel organisation having their stores online tend to focus on the quality level of website information to interest customer loyalty. In addition, the study byChua and Banerjee (2016) and Marinagi et al. (2015) supports the relationship between information quality and website quality by confirming that information accuracy, reliability as well as the understandability of the information positively influences website quality.

It was indicated in Figure 1 and Table 3 that system quality significantly influences website quality. According to Lee and Kozar (2006) and Bai et al. (2008), the success of travel website organisations not only depends on the quality of the information but also to a greater extent on the continual development of the system's quality aspects to provide higher levels of website quality, especially in cases where consumers evaluate one website among numerous alternatives. Hence, $\mathrm{H}_{2}$ is also supported in this study. This finding is supported by Bronner and de Hoog (2016) and Dedeke (2016), stating that maintaining website system quality enhance travel website business performance and motivate customer's perception to browse and purchasesintention due to the effectiveness of the website. The result supporting the path between overall website quality and customer loyalty $\left(\mathrm{H}_{3}\right)$ is consistent with previous empiricalfindings that travel website quality significantly influences consumer loyalty to the website and thereby enhance the customer willingness to re-visit the website (Flavia, Guinali \& Gurrea, 2006; Kim, Jin \& Swinney, 2009; Tsao et al., 2016). According to (RogerMonzoet al., 2015; Sun, Fong \& He, 2017), travel website information quality and system quality not only enhance the overall travel website quality but also significantly reduce customer online dissatisfaction and complaints, which further aid customer loyalty to the website.

\section{Conclusion and Recommendation}

The purpose of this study was to test statistically and apply selected quality components of DeLone and McLean's information success theory within a South African context. This study proposed three hypotheses using data that were collected from targeted research participants comprising consumers who had previous experience with making travel reservations from selected South African travel websites. All three hypotheses were supported significantly in this work. Prominently, this study provided evidence that consumer loyalty towards travel websites is influenced greatly by three essential and strategic concepts, namely information quality, system quality and website quality. This, therefore,provokes the need for South African organisations hosting travel websites to invest strategically in developing and improving their website quality to gain consumer loyalty and thereby enhance overall website success. However, to improve on website effectiveness, hospitality and tourism practitioners should adopt appropriate online strategy that accommodate the improvement of website in terms of the website information quality, system quality as well as the overall travel website quality in order to encourage customer loyalty to the website.

Limitations and Implications for Future Research: The supported hypotheses of this study as stipulated in the research model prove that a study of this nature makes asignificant contribution to travel and tourism practitioners andweb-managers. However, the findings cannot be generalised in their entirety since only a 
sample size of 189 online South African travel consumers was used in the eventual analysis. Therefore, future studies may be conducted by using and including data from other countries to be more informative in terms of cross-validation and investigating possible cultural invariance. Furthermore, a result comparison using a modified research model could be extended to other African countries to enhance further the current line of work. This ultimately will contribute new knowledge to the existing body of literature on the antecedents of consumer loyalty towards travel websites. Finally, travel organisations and consumers' loyalty to their respective websites were the focus of this study and did not cater for all other types of e-marketing and ecommerce websites. This shortcoming could be improved on with future research.

\section{References}

Aladwani, A. M. \& Palvia, P. C. (2002). Developing and validating an instrument for measuring user-perceived web quality. International Journal of U-and e-Services, 3(4), 1-18.

Amaro, S. \& Duarte, P. (2015). An integrative model of consumers' intentions to purchase travel online. Tourism Management, 46, 64-79.

Anderson, J. C. \& Gerbing, D. W. (1988). Structural equation modelling in practice: a review and recommended two-step approach. Psychological Bulletin 103(3), 411-423.

Bai, B., Law, R. \& Wen, I. (2008). The impact of website quality on consumer satisfaction and purchase intentions: evidence from Chinese online visitors. International Journal of Hospitality Management, 27, 391-402.

Bernardo, M., Marimon, F. \& Alonso-Almeida, M.M. (2012). Functional quality and hedonic quality: a study of the dimensions of e-service quality in online travel agencies. Information and Management Journal, $49,342-347$.

Bokhari, R. H. (2005). The relationship between system usage and user satisfaction: a meta-analysis. The Journal of Enterprise Information Management, 18(2), 211-234.

Bronner, F. \& De Hoog, R. (2016). Travel websites: changing visits, evaluations and posts. Annals of Tourism Research, 57, 94-112.

Cai, S. \& Jun, M. (2003). Internet users' perceptions of online service quality: a comparison of online buyers and information searchers. Managing Service Quality: An International Journal, 13(6), 504-519.

Cao, K. \& Yang, Z. (2016). A study of e-commerce adoption by tourism websites in China. Journal of Destination Marketing and Management, 5, 283-289.

Chua, A. Y. K. \& Banerjee, S. (2016). Helpfulness of user-generated reviews as a function of review sentiment, product type and information quality. Computer in Human Behavior, 54, 547-554.

Chavez, R., Yu, W., Gimenez, C., Fynes, B. \& Wiengarten, F. (2015). Customer integration and operational performance: the mediating role of information quality. Decision Support Systems, 80, 83-95.

Cheema, A. \& Papatla, P. (2010). Relative importance of online versus offline information for internet purchases: product category and internet experience effects. Journal of Business Research, 63, 979985.

Chen, X., Huang, Q. \& Davison, R. M. (2017). The role of website quality and social capital in building buyers' loyalty. International Journal of Information Management, 37, 1563-1574.

Chin, W. W. (1998). Issues and opinion on structural equation modelling. MIS Quarterly, 22(1), 7-16

Chua, A. Y. K. \& Banerjee, S. (2016). Helpfulness of user-generated reviews as a function of review sentiment, product type and information quality. Computer in Human Behaviour, 54, 547-554.

Chumpitaz, R. \& Paparoidamis, N. G. (2004). Service quality and marketing performance in business-tobusiness markets: exploring the mediating role of client satisfaction. Managing Service Quality, $14(2 / 3), 235-248$.

Cry, D., Hassanein, C., Head, M. \& Ivanov, A. (2007). The role of social presence in establishing loyalty in eservice environment. Interacting with Computer, 19(1), 43-56.

Dedeke, A. (2016). Travel web-site design: information task-fit, service quality and purchase intention. Tourism Management, 54, 541-554.

DeLone, W. H. \& McLean, E. R. (2002). Information systems success: the quest for the dependent variable, Information System Research, 39(1), 60-95.

DeLone, W. H. \& McLean, E. R. (2003). The DeLone and McLean Model of information systems success: a tenyear update. Journal of Management Information Systems/Spring, 19(4), 9-30. 
Elassy, N. (2015). The concepts of quality, quality assurance and quality enhancement. Quality Assurance in Education, 23(3), 250-261.

Field, A. (2009). Discovering statistics using SPSS. (3rd ed), London: Sage.

Flavia, C., Guinali, M. \& Gurrea, R. (2006). The role played by perceived usability, satisfaction and consumer trust on website loyalty. Information \& Management, 43, 1-14.

Fornell, C. \& Larcker, D. (1981). Structural equation models with unobservable variables and measurement error. Journal of Marketing Research 18(1), 39-50.

Fraering, M. \& Minor, M.S. (2006). Sense of community: An exploratory study of US consumers of financial services. International Journal of Bank Marketing 24(5), 284-306.

Ghasemaghaei, M. \& Hassanein, K. (2015). Online information quality and consumer satisfaction: the moderating roles of contextual factors - a meta-analysis. Information \& Management, 52, 965-981.

Ghasemaghaei, M. \& Hassanein, K. (2016). A macro model of online information quality perceptions: A review and synthesis of the literature. Computers in Human Behavior, 55, 972-991.

Hair, J. F., Ringle, C. M. \& Sarstedt, M. (2011). PLS-SEM: indeed, a silver bullet. Journal of Marketing Theory and Practice, 18(2), 139-152.

Hazen, B. T., Huscroft, J., Hall, D. J., Weigel, F. K. \& Hanna, J. B. (2014). Reverse logistics information system success and the effect of motivation. International Journal of Physical Distribution \& Logistics Management, 44(3), 201-220.

Henseler, J., Ringle, C. M. \& Sarstedt, M. (2015). A new criterion for assessing discriminant validity in variancebased structural equation modelling. Journal of the Academy of Marketing Science, 43(1), 115-135.

Hillner, B. E., Smith, T. J. \& Desch, C. E. (2000). Hospital and physician volume or specialization and outcomes in cancer treatment: importance in quality of cancer care. Journal of Clinical Oncology, 18(11), 23272340.

Hsu, M. H., Chang, C. M., Chu, K. K. \& Lee, Y. J. (2014). Determinants of repurchase intention in online groupbuying: the perspective of DeLone\& McLean IS success model and trust. Computers in Human Behavior, 36, 234-245.

Isfandyari-Moghaddam, A. (2016). Online searching: a guide to finding quality information efficiently and effectively. The Electronic Library, 34(4), 718-719.

International Organisation for Standardisation (ISO). (2009). Quality management: international standards organisation. Geneva, Switzerland: ISO Press and websites www.iso.org

Jeon, M. M. \& Jeong, M. (2017). Customers' perceived website service quality and its effects on e-loyalty. International Journal of Contemporary Hospitality Management, 29, 438-457.

Kim, J., Jin, B. \& Swinney, J.L. (2009). The role of e-tail quality, e-satisfaction and e-trust in online loyalty development process. Journal of Retailing \& Consumer Services, 16(4), 239-247.

King, J. E., Walpole, C. E. \& Lamon, K. (2007). Surf and turf wars online - growing implication of internet Gang violence. Journal of Adolescent Health, 41(6), 566-568.

Kuan, H. H., Bock, G. W. \& Vathanophas, V. (2008). Comparing the effects of website quality on customer initial purchase and continued purchase at e-commerce websites. Behaviour and Information Technology, 27(1), 3-16.

Law, R. \& Bai, B. (2008). How do the preferences of online buyers and browsers differ on the design and content of travel websites? International Journal of Contemporary Hospitality Management, 20(4), 388-400.

Lee, Y. \& Kozar, K. A. (2006). Investigating the effect of website quality on e-business success: an analysis hierarchy process (AHP) approach. Decision Support Systems, 42, 1383-1401.

Lin, H. F. (2007). The impact of website quality dimensions on customer satisfaction in the B2C e-commerce context. Total Quality Management and Business Excellence Journal, 18(4), 363-378.

Lwoga, E.T. (2013). Measuring the success of Library 2.0 technologies in the African context: the suitability of the DeLone and McLean's model. Campus-Wide Information Systems, 30(4), 288-307.

Malhotra, N. K. (2010). Marketing research: an applied orientation. 6th ed. New Jersey: Prentice-Hall.

Marinagi, C., Trivellas, P. \& Reklitis, P. (2015). Information quality and supply chain performance: the mediating role of information sharing. Procedia-Social \& Behavioral Sciences, 175, 473-479.

Moghavvemi, S. \& Salleh, N. A. M. (2014). Effect of precipitating events on information system adoption and use behavior. Journal of Enterprise Information Management, 27(5), 159-166.

Monczka, R. M., Handfield, R. B., Giunipero, L. C. \& Patterson, J. L. (2016). Purchasing and Supply Chain Management. 6th ed. Cengage learning. USA. 
Petter, S. \& McLean, E. R. (2009). A meta-analytic assessment of the Delone and McLean IS success model: an examination of IS success at the individual level. Information \& Management, 46, 159-166.

Ponte, E. B., Carvajal-Trujillo, E. \& Escobar-Rodriguez, T. (2015). Influence of trust and perceived value on the intention to purchase travel online: integrating the effects of assurance on trust antecedents. Tourism Management, 47, 286-302.

Ringle, C., Wende, S. \& Will, A. (2005). SmartPLS 2.0 (Beta). Hamburg, (www.smartpls.de).

Roger-Monzo, V., Marti-Sanchez, M. \& Guijarro-Garcia, M. (2015). Using online consumer loyalty to gain competitive advantage in travel agencies. Journal of Business Research, 68, 1638-1640.

Roky, H. \& Al Meriouh, Y. (2015). Evaluation by users of an industrial information (XPPS) based on the DeLone and McLean model for IS success. Procedia Economics \& Finance, 26, 903-913.

Roy, S. K. \& Balaji, M. S. (2015). Measurement and validation of online financial service quality (OFSQ). Marketing Intelligence \& Planning, 33(7), 1004-1026.

Sampaio, S. F. M., Dong, C. \& Sampaio, P. (2015). DQ ${ }^{2}$ - a framework for data quality-aware information management. Expert System with Applications, 42,8304-8326.

Silva, G. M. \& Goncalves, H. M. (2016). Causal recipes for customer loyalty to travel agencies: differences between online and offline customers. Journal of Business Research, 69, 5512-5518.

Sowter, J., Astin, F., Dye, L., Marshall, P. \& Knapp, P. (2016). Assessment of the quality and content of website health information about herbal remedies. Maturitas, 88, 16-22.

STATS SA. (2015). Tourism: jobs, the economy and spending. Available Online: http://www.statssa.gov.za/?p=9264 Sourced 17/02/2017.

Sun, S., Fong, D. K. C. \& He, R. L. S. (2017). An updated comprehensive review of website evaluation studies in hospitality and tourism. International Journal of Contemporary Hospitality Management, 29, 355-373.

Tam, C. \& Oliveira, T. (2016). Understanding the impact of m-banking on individual performance. Computers in Human Behavior, 61, 233-244.

Tenenhaus, M., Vinzi, V. E., Chatelin, Y. M. \& Lauro, C. (2005). PLS path modelling. Computational Statistics \& Data Analysis, 48(1), 159-205.

Toufaily, E., Ricard, L. \& Perrien, J. (2013). Customer loyalty to a commercial website: descriptive metaanalysis of the empirical literature and proposal of an integrative model. Journal of Business Research, $66,1436-1447$.

Tsao, W. C., Hsieh, M. T. \& Lin, T. M. Y. (2016). Intensifying online loyalty! The power of website quality and the perceived value of consumer/seller relationship. Industrial Management \& Data Systems, 116(9), 1987-2010.

Tseng, S. Y. \& Wang, C. N. (2016). Perceived risk influence on dual-route information adoption processes on travel websites. Journal of Business Research, 67, 2289-2296.

Tung, F. C. (2012). Exploring factors influencing Taiwan's tourism website customer satisfaction and intention. The International Journal of Organisational Innovation, 5, 217-223.

Wang, L., Law, R., Guillet, B. D., Hung, K. \& Fong, D. K. C. (2015). Impact of hotel website quality on online ebooking intentions: e-trust as a mediator. International Journal of Hospitality Management, 47, 108115.

Webster, R. \& Williams, P. (2005). An evaluation of the NHS direct online health information e-mail enquiry service quality of health information on the internet. Aslib Proceedings: New Information Perspective, $57(1), 48-62$.

Wetzels, M., Odekerken-Schroder, G. \& Van Oppen, C. (2009). Using PLS path modelling for assessing hierarchical construct models: guidelines and empirical illustration. Management Information Systems Quarterly, 33(1), 177-195.

Wolfinbarger, M. \& Gilly, M. C. (2003). ETAILQ: dimensionalizing, measuring and predicting e-tail quality. Journal of Retailing, 79(3), 183-198.

Wu, J. F. \& Chang, Y. P. (2016). Multichannel integration quality, online perceived value and online purchase intention: a perspective of land-based retailers. Internet Research, 26(5), 1228-1248.

Xiang, Z., Magnini, V. P. \& Fesenmaier, D. R. (2015). Information technology and consumer behavior in travel and tourism: insight from travel planning using the internet. Journal of Retailing \& Consumer Services, 22, 244-249.

Xinli, H. (2015). Effectiveness of information technology in reducing corruption in China: a validation of the DeLone and McLean information systems success model. The Electronic Library, 33(1), 52-64. 
Yoo, B. \& Donthu, N. (2001). Developing a scale to measure the perceived quality of an Internet shopping site (SITEQUAL). Quality Journal of Electronic Commerce, 2(1), 31-47.

Zhang, K., Min, Q., Zhenhua Liu, Z. \& Liu, Z. (2016). Understanding microblog continuance usage intention: an integrated model. Aslib Journal of Information Management, 68(6), 772-792.

Zhang, M. C. Q. \& Seydel, J. (2005). B2C e-commerce web site quality: an empirical examination. Industrial Management \& Data Systems, 105(5), 645-661.

Zhao, X. (2016). Competition, information and quality: evidence from nursing homes. Journal of Health Economic, 49, 136-152

Zheng, Y., Zhao, K. \& Stylianou, A. (2009). Information quality and system quality in online communities an empirical investigation. SICHCI 2009 Proceedings. Paper 8 http://aisel.aisnet.org/sighci2009/8.

\section{Appendix 1}

\section{SYSTEM QUALITY}

- The travel website uses audio elements properly

- The travel website uses animations/graphics properly

- The travel website uses multimedia features properly

\section{INFORMATION QUALITY}

- The travel website provides accurate information about the reservations that I want to make

- The travel website provides sufficient information when I try to make a transaction

- The information in the travel website is clear for me to make a travel reservation

\section{LOYALTY}

- I encourage friends and relatives to do business with this travel website

- I say positive things about this travel website to other people

- I will not switch from this travel website to making reservations any other way

- I will do more business with this site in the next few years

\section{WEBSITE QUALITY (OVERALL)}

- This travel website is of high quality

- The likely quality of this travel website is extremely high

- This travel website must be of very good quality

- Overall, this travel website is of very good quality 